Article

\title{
How Can Stores Sustain Their Businesses? From Shopping Behaviors and Motivations to Environment Preferences
}

\author{
Rachel J.C. Chen
}

Center for Sustainable Business and Tourism, 311 Conference Center Building, The University of Tennessee, Knoxville, TN 37996-4134, USA; E-mail: rchen@utk.edu; Tel.: 1-(865)-974-0505

Received: 2 January 2013 / Accepted: 18 January 2013 / Published: 5 February 2013

\begin{abstract}
The purpose of this study was to (1) discover consumer purchasing behaviors while shopping as a tourist and shopping at home, and (2) investigate tourist shopping preferences for an ideal shopping environment. A sample of 1,235 respondents participated in this study. Survey participants were asked to evaluate what store attributes they desired and what sources of information they used while selecting a store to shop in during their trips. Results indicate that consumers utilized various shopping channels while shopping in various environments. Also, different types of consumers exhibited clear preferences toward their ideal shopping environment. The results of this study are helpful for future service providers, tourism businesses, and tourism retailers to plan product development, provide better services, and equip a wider range of service skills.
\end{abstract}

Keywords: shopping behaviors; shopping environment

\section{Introduction}

In the dynamic and ever-changing field of hospitality and tourism, it has become imperative for researchers to understand how to best tailor services and products to tourists. When tourists travel to different areas, they spend a great amount of money on lodging, food and beverages, attractions, and activities. While a shopping place is not normally a primary attraction for most tourists, shopping has been well recognized as one of the most important and preferred activities among tourists in many destinations [1-3]. Shopping is unique to the tourist experience, in that many travelers feel as if their vacation is incomplete without some form of a retail experience [1,3]. As the economic impact of tourism shopping on the destination has increased in the past decades, and is of major significance, it is essential for both private and public sectors to gain awareness of tourism shopping patterns and preferences. 
Many local governments have been willing to invest in the environment and business opportunities surrounding a destination in order to entice tourists to stay longer and make more monetary contributions to the district $[3,4]$. In the past decades, studies have reported the importance of understanding customers' behaviors toward the shopping environment including the shopping location [3] and exterior designs [5], shopping emotions and satisfaction [6], willingness to buy [7], and tourist shopping route choice behaviors [8]. However, few studies investigated a holistic view of various shopping behaviors when the individual shops as a tourist or shops as a resident on a daily basis. The main purposes of the study were to discover consumer purchasing behaviors while shopping as a tourist and shopping at home, and what could be an ideal shopping environment from tourists' shopping perspectives. The research questions addressed in this study include: (1) to what extent are the perceptions of store atmosphere/environment associated with shopping motivation; and (2) to what extent are the shopping experiences associated with the perceptions of store atmosphere/environment among various consumer segments? It is hoped that this study will provide an understanding of how individuals utilize various shopping channels and how individuals allocate expenditures on various goods. Secondly, this study provides information relative to the impact shopping environment have on different segments' shopping decisions and satisfaction. Third, it sheds light on how individuals' shopping behaviors would be modified in terms of the role they play as residents or non-residents (tourists). The outcomes of this study are helpful for future service providers, tourism businesses, and tourism retailers to plan product development, provide better services, and equip a wider range of service skills. This following literature review section attempted to discover daily patronage of general consumers, shopping satisfaction levels of tourists, factors that influence tourists' shopping decisions, and souvenir buying intentions.

\section{Literature Reviews}

These days, consumers are more often identified with the way they consume things than their religion or culture [9]. The consumers could shop for personal or social motives. However, some retailers are increasingly finding that the shopping habits are often not planned [10]. As consumer behaviors get more unpredictable and in light of increasing competition, it is very important for retailers to develop the right strategies [11]. Foxall [12] identified three kinds of shopping behavior: hedonic, informational, and aversive. The hedonic group derives pleasure by owning or consuming goods, whereas the shoppers under the informational category shop to distinguish their social status from others. The aversive shopper attempts to avoid the presence of salespersons in order to enjoy their own shopping moments. Donovan, Rositer, Marcoolyn, and Nesdale [13] demonstrated that shoppers' emotional states and motivations at the time of shopping play a major role in predicting buying behaviors.

\subsection{Shopping Motivations}

Understanding the relationship between shopping motivations and the perceptions of store environment may assist retailers in providing a more effective marketing campaign to improve store atmosphere and enhance shopping experiences. Tauber [10] reported a number of motivations for shopping including personal (e.g., role playing, diversion from routine life, self-gratification, learning 
about new trends, physical activity for exercise, or sensory stimulation) and social motives (communicating with others with similar interests, status and authority, or pleasure of bargaining). The personal motives suggested by Tauber [10] are quite similar to the six categories that Arnold and Reynolds [14] suggested to divide hedonic shopping motives, including a) shopping for stimulation, (b) social shopping, (c) gratification shopping for stress relief, (d) idea shopping (to keep up with the trends), (e) role shopping (pleasure of shopping for others), and (f) value shopping (shopping for sales or bargains). Babin, Darden, and Griffin [15] asserted that the motives of hedonic shoppers are similar to those of the utilitarian shoppers. The only difference is that their motive is to satisfy their hedonic motives, experience fun, and amusement, whereas the goal of the utilitarian shoppers is to get the best value for money. However, two individuals might have two different hedonic responses based on their habituation to their life experiences [15].

Over the years, many researchers have maintained that people also shop to mingle with others. Cox, Cox, and Anderson [16] noted that one out of eight shoppers enjoyed interacting with other shoppers. For example, someone who enjoys shopping will be more easily influenced in a positive shopping environment. Childless women, especially, are more likely to enjoy interacting with others while shopping. Mathwick, Malhotra, and Rigdon [17] reported that goal-oriented shoppers want to make the best purchase in the least time possible. For the goal-oriented shoppers, shopping is an analytical exercise. According to Cox et al. [16], 80\% of the respondents agreed that they are thrilled when they find a real bargain. Mathwick et al. [17] affirmed that experiential shoppers derive pleasure and recreation by investing time in shopping. In addition to understanding the research findings of the shopping motivations and shopping behaviors, more retailers have strived to determine how they could reach out to their existing and potential customers through various shopping channels.

\subsection{Shopping Channels}

Various shopping channels (e.g., online shopping, catalog shopping, shopping in on-site stores, and television shopping, etc.) play vital roles in providing consumers' shopping opportunities and inducing shopping satisfaction and experiences on a daily basis. Previous studies have focused on investigating consumers' different shopping behaviors between online stores and traditional physical on-site stores [12,18-20]. Some of the most commonly cited reasons for buying online (through computers and/or mobile phones) were convenience of shopping from home, products not being available locally, and low prices. For example, Degeratu et al. [19] reported that online shoppers were likely to be less price-sensitive but more convenience-conscious, while Danaher et al. [18] suggested that online store shoppers were more sensitive to brand loyalty than those shoppers in physical on-site stores were.

Mathwick et al. [17] found that catalog shopping was predominantly a female activity. While one out of five internet respondents was a male, this number in the case of catalog shopping was one out of 20. The frequent catalog shoppers tended to be older and better educated than infrequent catalog shoppers [21]. They were also more likely to engage in inactive pursuits rather than sport activities and were more likely to perceive convenience as an important factor in their decisions to shop from catalogs than were infrequent catalog shoppers. Regarding television shopping, more than 10 million U.S. customers annually shopped from the number-one TV shopping channel, Quality Value Conveniences (QVC, www.qvc.com; HSN, www.hsn.com). The first TV shopping channel and now the second-largest TV shopping channel, the Home Shopping Network, was founded in 1982 in 
Florida (QVC, www.qvc.com; HSN, www.hsn.com). In addition to the shopping channel-related studies summarized above, segments (such as male and female) among shoppers have drawn significant attention in the literature.

\subsection{Shopping Segments}

Roy, Pedersen, and Hikmet [22] suggested that shopping is largely a female activity, particularly for grocery shopping. The authors reported that only $15 \%$ of the men surveyed believed that shopping for groceries was their primary responsibility. However, in the case of male clothing, 56\% of the respondents claimed to be primary shoppers. The level of enjoyment was found to be the highest among the male shoppers who considered shopping as a joint activity. Otnes and McGrath [23] reported that male shopping behaviors can be generally classified into three categories. The first is Grab and Go Shopping. This stereotype was found in both men and women. These shoppers just get what they want and leave as soon as possible. The second category is Whine and/or Wait. No noticeable whining (complaint) was found among the men who were surveyed. It is supposed that the idea of helping their partner keeps them happy. Activities like carrying things and entertaining children keep the men involved and give them a feeling of satisfaction. The third category is Fear of the Feminine. Men try to avoid buying products that have a feminine undertone.

Regarding the female segment's shopping behaviors, Thompson, Locander, and Pollio [24] reported that contemporary married women feel that they have the ultimate responsibility for the domestic tasks and they take it as a personal constraint more than their husbands. According to Moye and Kincade [25], women in different shopping environments have totally different shopping behaviors. They vary in terms of store patronage and attitudes. Moye and Kincade [25] classified clothes-buying behavior among female consumers into four categories. The first is highly involved bargain apparel shopper. They focus on bargains. This segment is not a very practical market for department stores. However, it is a good market for stores with everyday low prices such as discount stores. The second category is decisive apparel shopper. They have the characteristics of a bargain shopper but they buy the item without any hesitation if they like it. For such consumers, store layout is very important. The third category is confident apparel shopper. They shop independently and don't need any help. They are fashion conscious and like to keep their wardrobe up-to-date. Specialty stores will have an advantage in this segment. The fourth category is extremely involved appearance-conscious apparel shopper. This shopper believes that her reputation is affected by the way she dresses. Designer labels should be marketed to this segment. The literature discussed highlighted the different needs wants, and concerns of male and female shoppers. While tourists' shopping is on the rise, experiences and attitudes of female and male tourist shopping behavior remain under-investigated.

There are a variety of reasons that tourists travel, and these various sectors of travelers have different shopping patterns. It has become increasingly important for retailers to begin to cater to this group of consumers, and to be able to clearly identify various needs and motivations of each type of traveler [26]. 


\subsection{Tourist Shopping Behaviors}

While the economic explosion of tourism activities has received much attention in recent years, the shopping behaviors of tourists have not been as frequently investigated [27,28]. Verbeke [29] suggested that indicators such as personal characteristics, the shop during the visit, and type of purchases have proved to be useful in analyzing tourism shopping. The longer a tourist stays in a shopping area, the stronger the leisure aspect becomes. Although Spencer, Kim, and Holecek [30] found that shopping was rarely the primary reason for tourists to visit a place, as one of the most universal and popular tourism activities, shopping becomes a focal point for tourism planners and managers.

Tourists' shopping satisfaction. Satisfaction for domestic travelers results primarily from obtaining a product with attributes that they find important. Turner and Reisinger [26] found that tourists follow a specific shopping pattern of product choice based upon product attributes, which predicts the tourist's satisfaction. In the United States, shopping is one of the most universal tourist activities. Souvenirs are some of the items most frequently purchased by travelers. They can be categorized as souvenirs purchased by the tourist for personal use, or items purchased as gifts for others [1]. Studies have shown that nearly $70 \%$ of tourist shoppers purchased souvenir items for family and friends during their travel. Kim and Littrell [1] indicated that tourists' attitudes toward the uniqueness of a souvenir were affected positively, and few differences were discovered between ethnic and recreational tourists. Overall, shopping has proven to be one of the most frequent activities of tourists around the world. As a result, much recent attention has focused on tourists' shopping activity [31]. Regardless of the attraction or regional destination being visited, visitors' shopping behaviors and the revenue generated by tourism shopping should be continually investigated.

\section{Methods}

This study was an attempt to discover consumer purchasing behaviors while shopping as a tourist and shopping at home. This study employed mail surveys to gather data from households of the Southeastern US region including 9 states. During the years of 2007-2008, two thousand five hundred self-administered questionnaires were mailed to randomly selected households. The name list was provided by a reliable consultant company that provided the list for survey purpose. Of these questionnaires, 1,235 completed and usable questionnaires were returned, yielding a response rate of 49.4 percent. Returned surveys were coded and entered into the SPSS 17.0 program. Mean values for a variety of question responses of male and female groups were compared using the SPSS program. After determining normality in data by running a histogram and using the Komogorov-Simirnov statistic with a Lillefors significance level, a non-parametric test (the Mann Whitney test) was used in the study [32]. Mann Whitney test and Chi-Square test were used to test the null hypothesis that no perception differences existed between two kinds of gender populations. The Mann Whitney test was used with interval data and Chi-Square was used with nominal variables. Statistically significant group differences are highlighted and discussed.

The consumers surveyed were asked questions concerning their perceptions regarding their uses of different shopping channels (e.g., home shopping channel, catalog shopping, internet shopping, and store shopping), various factors that affect the way they shop (e.g., economic downtimes, and store 
return policy), reasons why they buy souvenirs during their trips, what specific store attributes they desire when shopping as a tourist, and what kind of souvenirs they purchased during their most recent leisure vacation that was more than one hundred miles one-way in the US. The results of this project will provide useful information for marketing professionals to assist them in planning, advertising, and promotions.

\section{Results}

Of the 1,235 useful responses, 456 were males and 779 were females. The following is a summary of the key findings related to the shopping channel decisions, shopping behaviors (at home as a daily consumer and on the road as a tourist), and store choices.

Shopping channel decisions. Approximately sixty-one percent of respondents reported that television commercials influence their purchasing decisions. When asked if they have purchased items from a home shopping channel like QVC in the past 12 months, only $7.5 \%$ of male and $6.9 \%$ of female respondents said "yes" respectively $(p<0.82)$. Based on the Chi-square significance, there was not a significant difference in male and female purchasing of items from QVC in the past 12 months. Approximately thirty-five percent of male and $72 \%$ of female respondents indicated they had purchased products via a catalog $(p<0.0001)$, and $67 \%$ of male and $69 \%$ of female respondents said that they do shop online $(p<0.56)$ in the past year while shopping at home.

Store Shopping reactions. A seven point likert scale ( $1=$ not very likely, $7=$ very likely) was used to assess the overall participants reaction relative to the quality of store shopping services. "Leave a store without making a purchase because of bad service" (mean = 5.0), "Purchase something I don't need because of superior service" (mean = 3.3), "Make an unneeded purchase because of a high pressure salesperson" (mean $=2.6)$, and "Complain to a superior because of bad service" $($ mean $=4.3)$ were rated by all participants.

The males ranked "Leave a store without making a purchase because of bad service" (mean $=4.9$ ), while females rated "Leave a store without making a purchase because of bad service" (mean = 5.0). Males reported, "Purchase something I don't need because of superior service" (mean = 2.9), while females reported "Purchase something I don't need because of superior service" (mean $=3.5$ ). Differences in the "Purchase something I don't need because of superior service" $(p<0.0001)$ and "Make an unneeded purchase because of a high pressure salesperson" ( $p<0.0001)$ categories for males and females were statistically significant (Table 1).

Purchasing Decisions. Differences in the factors that influence shopping decisions of male and female participants were statistically significant. When asked if inflation or economic downtimes affect the way they shop and their travel decision, 39\% of males and 32\% of female respondents said "yes" respectively $(p<0.03)$. When asked if they are fearful of buying items while traveling due to the fact that they cannot return the items, $21 \%$ of males and $30 \%$ of female respondents said "yes" respectively $(p<0.01)$. When asked why they buy souvenirs during their trips - the most frequent mentioned reasons were: gifts for family members (males $(72 \%)$; female $(88 \%) ; p<.0001)$, Gifts for friends (males (54\%); female (75\%); $p<0.0001)$, and gifts for personal use and consumption (males $(78 \%)$; female $(79 \%) ; p<0.63)$. When asked what percentage of their money was spent on souvenirs during their most recent trip, 432 males said "10\%" and 692 females said'18\%' respectively $(p<0.0001)$ (Table 2). 
Table 1. Store shopping reactions and decisions.

\begin{tabular}{lccc}
\hline \multicolumn{1}{c}{ Characteristic } & Male & Female & Signif. (MW) \\
\hline Leave a store without making a purchase & $\mathrm{N}=456$ & $\mathrm{~N}=779$ & 0.79 \\
because of bad service & 4.9 & 5.0 & \\
Purchase something I don't need because & $\mathrm{N}=454$ & $\mathrm{~N}=778$ & $0.0001^{* * *}$ \\
of superior service & 2.9 & 3.5 & \\
Make an unneeded purchase because of a & $\mathrm{N}=456$ & $\mathrm{~N}=779$ & $0.0001^{* * *}$ \\
high pressure salesperson & 2.1 & 2.8 & 0.80 \\
Complain to a superior because of bad & $\mathrm{N}=455$ & $\mathrm{~N}=777$ & 4.3 \\
service & 4.3 & 4.3 & \\
\hline
\end{tabular}

$1=$ no change, $7=$ major change (reported with average grade). $* * *$ Significant at the 0.01 level. $* *=$ Significant at the 0.05 level. $*=$ Significant at the 0.1 level. Signf. $=$ Significant level. MW = Mann Whitney test.

Table 2. Macro factors that influence purchasing decisions.

\begin{tabular}{|c|c|c|c|}
\hline Characteristic & Male & Female & Signif. \\
\hline $\begin{array}{l}\text { Macro factors that influence their shopping } \\
\text { decisions }\end{array}$ & $\begin{array}{l}\mathrm{N} \\
\%\end{array}$ & $\begin{array}{l}\mathrm{N} \\
\%\end{array}$ & \\
\hline $\begin{array}{l}\text { If inflation or economic downtimes affect } \\
\text { the way they shop }\end{array}$ & $\begin{array}{c}N=456 \\
\text { Yes }=39 \% \\
\text { No }=61 \%\end{array}$ & $\begin{array}{c}\mathrm{N}=779 \\
\text { Yes }=32 \% \\
\text { No }=68 \%\end{array}$ & $0.03 * * \mathrm{C}$ \\
\hline $\begin{array}{l}\text { If they are fearful of buying items while } \\
\text { traveling due to the fact that they cannot } \\
\text { return the items }\end{array}$ & $\begin{array}{c}\mathrm{N}=455 \\
\mathrm{Yes}=21 \% \\
\text { No }=79 \%\end{array}$ & $\begin{array}{c}\mathrm{N}=776 \\
\mathrm{Yes}=30 \% \\
\mathrm{No}=70 \%\end{array}$ & $0.01 * * \mathrm{C}$ \\
\hline \multicolumn{4}{|l|}{ Why they buy souvenirs during the trips } \\
\hline Gifts for family members & $\begin{array}{c}N=454 \\
\text { Yes }=72 \% \\
\text { No }=28 \%\end{array}$ & $\begin{array}{c}\mathrm{N}=777 \\
\mathrm{Yes}=88 \% \\
\mathrm{No}=12 \%\end{array}$ & $0.0001 * * * \mathrm{C}$ \\
\hline Gifts for friends & $\begin{array}{c}\mathrm{N}=452 \\
\mathrm{Yes}=54 \% \\
\mathrm{No}=46 \%\end{array}$ & $\begin{array}{c}\mathrm{N}=772 \\
\mathrm{Yes}=75 \% \\
\mathrm{No}=25 \%\end{array}$ & $0.0001 * * * \mathrm{C}$ \\
\hline Gifts for co-workers & $\begin{array}{c}\mathrm{N}=456 \\
\mathrm{Yes}=12 \% \\
\text { No }=88 \%\end{array}$ & $\begin{array}{l}\mathrm{N}=775 \\
\mathrm{Yes}=12 \% \\
\mathrm{No}=88 \%\end{array}$ & $0.85^{\mathrm{C}}$ \\
\hline Gifts for personal use and consumption & $\begin{array}{c}\mathrm{N}=453 \\
\mathrm{Yes}=78 \% \\
\text { No }=22 \%\end{array}$ & $\begin{array}{c}\mathrm{N}=766 \\
\mathrm{Yes}=79 \% \\
\text { No }=21 \%\end{array}$ & $0.63^{\mathrm{C}}$ \\
\hline $\begin{array}{l}\text { What percentage of their money was spent } \\
\text { on souvenirs during their most recent trips }\end{array}$ & $\begin{array}{c}\mathrm{N}=432 \\
10 \%\end{array}$ & $\begin{array}{c}\mathrm{N}=692 \\
18 \%\end{array}$ & $0.0001^{* * * \mathrm{C}}$ \\
\hline
\end{tabular}

$* * *=$ Significant at the 0.01 level. $* *=$ Significant at the 0.05 level. $*=$ Significant at the 0.1 level. Signf. $=$ Significant level. $\mathrm{C}=$ Chi-square test.

Perceptions toward store attributes when shopping as a tourist. When participants were asked about what specific store attributes make them feel about purchasing (on a one to seven scale, where $1=$ not at all important, and $7=$ the most important), the most important store attributes according to males were "friendly staff" (5.3), "reasonable prices" (5.3), "neatness and cleanliness of store interior" (5.3). 
For female consumers, the most important store attributes were "reasonable prices" (5.8), "neatness and cleanliness of store interior" (5.7), "friendly staff" (5.6), "wide merchandise selection" (5.5), "safety" (5.4), "days and hours open for shopping" (5.4), "socializing with my travel companions" (5.1), and "product brands" (5.1). Differences in the "neatness and cleanliness of store interior" $(p<0.0002)$, "safety" ( $p<0.0001)$, "socializing with my travel companions" $(p<0.0001)$, "unique architecture" $(p<0.0001)$, "wide merchandise selection" ( $p<.0001)$, "product brands" $(p<0.015)$, "reasonable prices" $(p<.0001)$, and "days and hours open for shopping" $(p<0.0001)$ categories for males and females were statistically significant at the 0.05 level (Table 3 ).

Table 3. Perceptions toward store attributes when shopping as a tourist.

\begin{tabular}{|c|c|c|c|}
\hline Characteristic & Male & Female & $\begin{array}{l}\text { Signif. } \\
\text { (MW) }\end{array}$ \\
\hline Friendly staff & $\begin{array}{c}\mathrm{N}=456 \\
5.3\end{array}$ & $\begin{array}{c}\mathrm{N}=779 \\
5.6\end{array}$ & 0.16 \\
\hline Neatness and cleanliness of store interiors & $\begin{array}{c}\mathrm{N}=449 \\
5.3\end{array}$ & $\begin{array}{c}\mathrm{N}=777 \\
5.7\end{array}$ & $0.0002 * * *$ \\
\hline Unique architecture & $\begin{array}{c}\mathrm{N}=447 \\
4.9\end{array}$ & $\begin{array}{c}\mathrm{N}=774 \\
3.7\end{array}$ & $0.0001^{* * *}$ \\
\hline Easy entry and exit & $\begin{array}{c}\mathrm{N}=455 \\
4.4\end{array}$ & $\begin{array}{c}\mathrm{N}=769 \\
4.4\end{array}$ & 0.95 \\
\hline Reflective of local culture & $\begin{array}{c}\mathrm{N}=454 \\
4.5\end{array}$ & $\begin{array}{c}\mathrm{N}=768 \\
4.7\end{array}$ & 0.34 \\
\hline Close to airport & $\begin{array}{c}\mathrm{N}=449 \\
2.7\end{array}$ & $\begin{array}{c}\mathrm{N}=776 \\
2.5\end{array}$ & 0.26 \\
\hline Close to hotel $/$ motel & $\begin{array}{c}\mathrm{N}=455 \\
3.3\end{array}$ & $\begin{array}{c}\mathrm{N}=776 \\
3.3\end{array}$ & 0.95 \\
\hline Safety & $\begin{array}{c}\mathrm{N}=455 \\
4.7\end{array}$ & $\begin{array}{c}\mathrm{N}=778 \\
5.4\end{array}$ & $0.0001 * * *$ \\
\hline Socializing with my travel companions & $\begin{array}{c}\mathrm{N}=455 \\
3.1\end{array}$ & $\begin{array}{c}\mathrm{N}=771 \\
5.1\end{array}$ & $0.0001 * * *$ \\
\hline Wide merchandise selection & $\begin{array}{c}\mathrm{N}=456 \\
4.9\end{array}$ & $\begin{array}{c}\mathrm{N}=779 \\
5.5\end{array}$ & $0.0001 * * *$ \\
\hline Product brands & $\begin{array}{c}\mathrm{N}=455 \\
4.8\end{array}$ & $\begin{array}{c}\mathrm{N}=778 \\
5.1\end{array}$ & $0.015^{* *}$ \\
\hline Reasonable prices & $\begin{array}{c}\mathrm{N}=454 \\
5.3\end{array}$ & $\begin{array}{c}\mathrm{N}=778 \\
5.8\end{array}$ & $0.0001 * * *$ \\
\hline Days and hours open for shopping & $\begin{array}{c}\mathrm{N}=453 \\
4.7\end{array}$ & $\begin{array}{c}\mathrm{N}=779 \\
5.4\end{array}$ & $0.0001 * * *$ \\
\hline
\end{tabular}

$1=$ not at all important, $7=$ the most important (reported with average grade). $* * *=$ Significant at the 0.01 level. $* *=$ Significant at the 0.05 level. $*=$ Significant at the 0.1 level. Signf. $=$ Significant level. MW $=$ Mann Whitney test.

Sources of Information. The three most important sources of information used while selecting a store to shop in during their trips for male consumers were friends $(50 \%)$, previous experience $(53 \%)$, and internet (47\%). The most popular commercial information sources for males were television (42\%) and attraction brochures (41\%). The three most common sources of information used while selecting a 
store to shop in during trips for females consumers were friends (79\%), previous experience (73\%), and relatives (57\%). The most popular commercial information sources for females were attraction brochures (47\%) and television (47\%). Males were more likely to use automobile clubs, newspaper advertisements, and billboard as sources of information than female consumers. The results indicate that the two types of consumers using various sources of information [previous experiences $(p<0.001)$, relatives $(p<0.001)$, friend $(p<0.001)$, magazine articles $(p<0.02)$, automobile clubs $(p<0.02)$, newspaper advertisements $(p<0.02)$, and billboard $(p<0.04)]$ were statistically significant at the 0.05 level (Table 4).

Table 4. Sources of information.

\begin{tabular}{|c|c|c|c|}
\hline \multirow[t]{3}{*}{ Characteristic } & Male & Female & \multirow[t]{3}{*}{ Signif. } \\
\hline & $\mathbf{N}$ & $\mathbf{N}$ & \\
\hline & $\%$ & $\%$ & \\
\hline \multirow{3}{*}{ Friends } & $\mathrm{N}=456$ & $\mathrm{~N}=779$ & \multirow{3}{*}{$0.001 * * \mathrm{C}$} \\
\hline & Yes $=50 \%$ & Yes $=79 \%$ & \\
\hline & $\mathrm{No}=50 \%$ & $\mathrm{No}=21 \%$ & \\
\hline \multirow{3}{*}{ Previous experience } & $\mathrm{N}=456$ & $\mathrm{~N}=779$ & \multirow{3}{*}{$0.001 * * \mathrm{C}$} \\
\hline & Yes $=53 \%$ & Yes $=73 \%$ & \\
\hline & $\mathrm{No}=47 \%$ & $\mathrm{No}=27 \%$ & \\
\hline \multirow{3}{*}{ Internet } & $N=456$ & $\mathrm{~N}=778$ & \multirow{3}{*}{$0.13^{\mathrm{C}}$} \\
\hline & Yes $=47 \%$ & Yes $=42 \%$ & \\
\hline & $\mathrm{No}=53 \%$ & $\mathrm{No}=58 \%$ & \\
\hline \multirow{3}{*}{ Television } & $N=455$ & $\mathrm{~N}=776$ & \multirow{3}{*}{$0.27^{\mathrm{C}}$} \\
\hline & Yes $=42 \%$ & Yes $=47 \%$ & \\
\hline & $\mathrm{No}=58 \%$ & $\mathrm{No}=53 \%$ & \\
\hline \multirow{3}{*}{ Attraction brochures } & $N=456$ & $N=779$ & \multirow{3}{*}{$0.13^{\mathrm{C}}$} \\
\hline & Yes $=41 \%$ & Yes $=47 \%$ & \\
\hline & $\mathrm{No}=59 \%$ & $\mathrm{No}=53 \%$ & \\
\hline \multirow{3}{*}{ Relatives } & $\mathrm{N}=456$ & $\mathrm{~N}=777$ & \multirow{3}{*}{$0.001 * * \mathrm{C}$} \\
\hline & Yes $=42 \%$ & Yes $=57 \%$ & \\
\hline & $\mathrm{No}=58 \%$ & $\mathrm{No}=43 \%$ & \\
\hline \multirow{3}{*}{ Magazine articles } & $\mathrm{N}=456$ & $\mathrm{~N}=778$ & \multirow{3}{*}{$0.02 * \mathrm{C}$} \\
\hline & Yes $=35 \%$ & Yes $=44 \%$ & \\
\hline & $\mathrm{No}=65 \%$ & $\mathrm{No}=56 \%$ & \\
\hline \multirow{3}{*}{ Automobile clubs } & $\mathrm{N}=450$ & $\mathrm{~N}=767$ & \multirow{3}{*}{$0.02 *^{\mathrm{C}}$} \\
\hline & Yes $=12 \%$ & Yes $=4 \%$ & \\
\hline & $\mathrm{No}=88 \%$ & $\mathrm{No}=96 \%$ & \\
\hline \multirow{3}{*}{ Newspaper advertisements } & $\mathrm{N}=450$ & $N=765$ & \multirow{3}{*}{$0.02 * \mathrm{C}$} \\
\hline & Yes $=30 \%$ & Yes $=22 \%$ & \\
\hline & $\mathrm{No}=70 \%$ & $\mathrm{No}=78 \%$ & \\
\hline \multirow{3}{*}{ Billboard } & $N=455$ & $\mathrm{~N}=756$ & \multirow{3}{*}{$0.04 * \mathrm{C}$} \\
\hline & Yes $=37 \%$ & Yes $=29 \%$ & \\
\hline & $\mathrm{No}=63 \%$ & $\mathrm{No}=71 \%$ & \\
\hline
\end{tabular}

$0 * * *=$ Significant at the 0.01 level. $* *=$ Significant at the 0.05 level. $*=$ Significant at the 0.1 level. Signf. $=$ Significant level. $\mathrm{C}=$ Chi-square test. 


\section{Discussion and Conclusion}

In domestic and international tourism, the second largest expenditure of tourists is on shopping. Shopping expenditure, in some countries, can even be more significant than expenditure on accommodation. The key findings of this study are that shopping motivations, problem perceptions, and store-attribute-influence differences exist between females and males. Females are more likely to spend money on souvenirs during their trips, are fearful of buying items while traveling because they cannot return the items, and are less likely to have their shopping behavior influenced by inflation or economic downtimes. Females were more likely to purchase something they don't need and make an unneeded purchase than males when they receive superior service and meet high pressure salesperson at tourist souvenir stores. In addition, females' purchasing motivations are more likely to be affected by various souvenir store attributes including "neatness and cleanliness of store interior", "wide merchandise selection", "product brands", "reasonable prices", and "days and hours open for shopping.

Males are more likely to use automobile clubs, newspaper advertisements, and billboard as sources of information than female consumers while females are more likely to use previous experiences, relatives, friend, and magazine articles as sources of information than males.

Based on the results of the study, females may be the main target of store layout and design. Even for the male stores, female opinions need to be taken into consideration store layout and product assortment decisions. It is found that it is the combined effect of various environmental cues that affect the tourists' shopping behaviors. Also, stores with incomplete selection of products would be at a disadvantage. The shopping experience is a combination of tourists' behaviors, perceptions, expectations, and attitudes towards their shopping decisions. More implications may include (1) the authentic of merchandise within the US region should be well sustained, (2) shopping activities should be presented as a part of local destination cultures, and (3) tourism marketing venues should be enriched strategically based on the needs and wants of the tourist shoppers.

Understanding the factors that motivate individuals is a central concept in attempts to gain knowledge of tourists' shopping behaviors. A survey to help management identify destination problems and marketing segments makes a good future study. Because of budget constraints, this study randomly selected limited households in the US mainly. And those participants were limited to answer questions based on their most recent trip that was at least one-hundred miles away from their residential home in the US. Future studies may consider including international samples and more diverse segments such as cultural visitors, business groups, leisure visitors, and visitors with disabilities.

\section{Acknowledgements}

The author would like to thank Harry Timmermans for contributing his very valuable insights to this study.

\section{References}

1. Kim, S.; Littrell, M. Souvenir buying intentions for self versus others. Annals ourism Research 2001, 28, 638-657. 
2. Snepenger, J.D.; Murphy, L.; O’Connell, R.; Gregg, E. Tourists and residents use of a shopping space. Annals Tourism Research 2003, 30, 567-580.

3. Yuksel, A. Tourist shopping habitat: Effects on emotions, shopping value and behaviours. Tourism Managemen 2007, 28, 58-69.

4. Lin, Y.I. Evaluating a servicescape: The effect of cognition and emotion. International Journal of Hospitality Management 2004, 23, 163-178.

5. Turley, W.L.; Milliman, E.R. Atmospheric effects on shopping behaviour: A review of the experimental evidence. J. Business Research 2000, 49, 193-211.

6. Machleit, A.K.; Mantel, P.S. Emotional response and shopping satisfaction: Moderating effects of shopper attributions. J. Business Research 2001, 54, 97-106.

7. Baker, L.; Levy, M.; Grewal, D. An experimental approach to making retail store environmental decisions. J. Retailing 1992, 68, 445-460.

8. Kemperman, A.D.A.M.; Borgers, A.W.J.; Timmermans, H.J.P. Tourist shopping behavior in a historic downtown area. Tourism Management 2009, 30, 208-218.

9. Mooija, M.D.; Hofstede, G. Convergence and divergence in consumer behavior: Implications for international retailing. J. Retailing 2002, 78, 61-69.

10. Tauber, E.M. Marketing notes and communications: Why do people shop? Journal of Marketing 1972, 36, 46-59.

11. Leszczyc, P.T.L.P.; Sinha, A.; Timmermans, H.J.P. Consumer store choice dynamics: An analysis of the competitive market structure for grocery stores. J. Retailing. 2000, 76, 323-345.

12. Fox, E.; Montgomery, A.L.; Lodish, L.M. Consumer shopping and spending across retail formats. J. Business 2004, 77, s25-s60.

13. Donovan, R.J.; Rositer, J.R.; Marcoolyn, G.; Nesdale, A. Store atmosphere and purchasing behavior. J. Retailing 1994, 70, 283-294.

14. Arnold, M.J.; Reynolds, K.E. Hedonic shopping motivations. J. Retailing 2003, 79, 77-95.

15. Babin, B.J.; Darden, W.R.; Griffin, M. Work and/or fun: measuring hedonic and utilitarian value. J. Consumer Research 1994, 20, 644-656.

16. Cox, A.D.; Cox, D.; Anderson, R.D. Reassessing the pleasures of store shopping. J. Business Research 2003, 58, 250-259.

17. Mathwick, C.; Malhotra, N.K.; Rigdon, E. The effect of dynamic retail experiences on experiential perceptions of value: An internet and catalog comparison. J. Retailing. 2002, 78, 51-60.

18. Danaher, P.J.; Wilson, J.W.; Davis, R. A comparison of online and offline Consumer Brand Loyalty. Marketing Science 2003, 22, 461-476.

19. Degeratu, A.; Rangaswamy, A.; Wu, J. Consumer choice behavior in online and traditional supermarkets: The effects of brand name, price, and other search attributes. Inter. J. Research Marketing 2000, 17, 55-78.

20. Zhang, J.; Wedel, M. The Effectiveness of customized promotions in online and offline stores. J. Marketing Research 2009, 46, 190-206.

21. Cynthia, J.R.; Pi-Nan Rosa, L. Apparel catalog patronage: Demographic, lifestyle and motivational factors. Psychology and Marketing 1992, 9, 275-296.

22. Roy, R.; Pedersen, B.; Hikmet, N. Married males and shopping: Are they sleeping partners? Inter. J. Retail Distribution Management 1995, 23, 27-33. 
23. Otnesa, C.; McGrath, M.A. Perceptions and realities of male shopping behavior. J. Retailing 2001, 77, 111-137.

24. Thompson, C.J.; Locander, W.B.; Pollio, H.R. The lived meaning of free choice: An existentialphenomenological description of everyday consumer experiences of contemporary married women. J. Consumer Research 1990, 17, 346-361.

25. Moye, L.N.; Kincade, D.H. Shopping orientation segments: exploring differences in store patronage and attitudes toward retail store environments among female apparel consumers. Inter. J. Consumer Studies 2003, 27, 58-71.

26. Turner, L.; Reisinger, Y. Shopping satisfaction for domestic tourists. J. Retailing Consumer Services 2001, 8, 15-27.

27. Wong, J.R.; Law, R. Difference in shopping satisfaction levels: a study of tourists in Hong Kong. Tourism Management 2003, 24, 401-410.

28. Yuksel, A. Shopping experience evaluation: A case of domestic and international visitors. Tourism Management 2004, 25, 751-759.

29. Verbeke, M.J. Leisure shopping: A magic concept for the tourism industry? Tourism Management 1991, 12, 9-14.

30. Spencer, D.M.; Kim, D.; Holecek, D.F. An investigation of tourists' shopping behavior. Travel, Tourism, and Recreation Resource Center, Michigan State University, East Lansing, MI, USA, 2002.

31. Govers, R.; van Hecke, E.; Cabus, P. Delineating Tourism: Defining the Usual Environment. Annals Tourism Research 2008, 35, 1053-1073.

32. Rice, J. Mathematical Statistics and Data Analysis, 3rd ed.; University of Berkeley: Berkeley, CA, USA, 2006. Available online: http://www.stat.berkeley.edu/ rice/Book3ed/p442.pdf (accessed on 25 October 2010).

(C) 2013 by the authors; licensee MDPI, Basel, Switzerland. This article is an open access article distributed under the terms and conditions of the Creative Commons Attribution license (http://creativecommons.org/licenses/by/3.0/). 